\title{
Infection of a Calf with the Enteric Coronavirus Strain Paris
}

\author{
Brief Report
}

With 3 Figures

Accepted July 12, 1982

\begin{abstract}
Summary
A tissue-culture-grown enteric coronavirus infected the whole of the gastrointestinal tract and caused enteritis and diarrhoea in a 10-day-old gnotobiotic Friesian calf. Diarrhoea occurred 2 days after inoculation and excretion of virus in faeces and rectal swabs increased until necropsy at 3 days. Virus growth, as detected by indirect immunofluorescence, virus isolation, and thin section electron microscopy, was most extensive in the epithelium of the colon and rectum at 3 days after inoculation. No virus was detected in other organs or in the pleural, peritoneal and oropharyngeal cavities. The origin and host specificity of this coronavirus is discussed.
\end{abstract}

A number of coronaviruses causing gastroenteritis have been isolated from hosts as diverse as calves $(19)$, mice $(2,11)$, pigs $(9,16)$ and turkeys (22). However, at present there is no conclusive evidence involving coronaviruses in human gastroenteritis; coronaviruses of man have so far only been shown to cause mild upper respiratory tract infections (14). In addition to these animal enteric coronaviruses, coronavirus-like particles (CVLPs) have been identified in faeces from calves (18), cats (10), dogs (26), monkeys (5) and man $(6,17,27)$, but their nature and role in disease is unclear (14). CVLPs have failed to grow in tissue culture; the possible exceptions being the reported growth of human $(3,4)$ and

* Present address: Welleome Research Unit, Christian Modical College Hospital, Vellore, Tamil Nadu, India. 
cat (10) CVLPs in organ eultures. The relationship of CVLPs to coronaviruses is not clear at present.

Recently, however, isolates of a coronavirus have been reported from faeces of neonates from an outbreak of necrotising enterocolitis in France (29). The characterization of these isolates is important in order to resolve their origin and to determine whether they are indeed human enteric coronaviruses. It has been suggested by some workers that they may be of bovine origin (14), as several of these isolates grew in human rectal tumour cells of the HRT 18 line (31), were acid resistant and agglutinated erythrocytes, as has been described for bovine coronavirus (BCV) (12). Furthermore, these isolates had closely similar polypeptide profiles to $\mathrm{BCV}$ and cross-reacted with antisera to $\mathrm{BCV}$ in an indirect immunofluorescence (IIF) test (LAPORTE, unpublished results). The behaviour of one of these isolates, $\mathrm{CV}$ Paris in a susceptible bovine is an obvious prerequisite to clarify their identity.

Fourth passage CV Paris isolate was grown in monolayer cultures of HRT 18 cells at $37^{\circ} \mathrm{C}$ as previously described for BCV (13). The monolayers were harvested 3 days later, frozen and thawed once and stored at $-70^{\circ} \mathrm{C}$. A New Zealand white rabbit was bled before immunization to provide preimmune serum. A preparation of purified virus $\left(10^{9}\right.$ particles $\left./ \mathrm{ml}\right)$, of density $1.18 \mathrm{~g} / \mathrm{ml}$ in a sucrose gradient, was emulsified with an equal volume of Freund's complete adjuvant (FCA). One ml of the emulsion was injected subcutaneously into the rabbit at multiple sites. The rabbit was given a further one $\mathrm{ml}$ of virus emulsion in FCA intraperitoneally one month after the first inoculation and bled out a week later. Both the preimmune and the immune sera were adsorbed overnight at $4^{\circ} \mathrm{C}$ with acetone-dried bovine liver powder (Sigma Chemical Company Ltd., Poole, Dorset), using $100 \mathrm{mg}$ powder $/ \mathrm{ml}$ serum.

A Friesian calf derived by caesarian section at 260 days of gestation was maintained in a germ-free environment (32). At 10 days of age the calf was given orally $10 \mathrm{ml}$ of 5 th passage HRT 18 grown CV Paris stock, containing $10^{7.3}$ PFU/ml. Faeces and throat, conjunctival and rectal swabs were taken just before inoculation and then daily until autopsy 3 days after inoculation. These samples were plated on blood agar for bacterial isolation and inoculation onto HRT 18 cells for isolation of coronaviruses. 10 per cent $w / v$ suspensions of faeces were also examined by negative staining (8). Rectal temperatures were taken daily after caesarian section and after virus inoculation. At postmortem, the trachea, lung, tonsil, thymus, spleen, liver, kidney, salivary gland, thyroid, adrenal gland, conjunctiva, the submandibular retropharyngeal, pharyngeal and mesenteric lymph nodes, and abomasum, duodenum, jejunum, ileum, colon, rectum and faeces were collected and stored at $-70^{\circ} \mathrm{C} .10$ per cent $\mathrm{w} / \mathrm{v}$ suspensions were prepared from luman contents collected from the gastrointestinal tract (GI). Tissue samples were thawed at $37^{\circ} \mathrm{C}$ and homogenized with sand in TenBroeck grinders to obtain 5 per cent $w / v$ suspensions. The suspensions of the tissues, lumen contents and faeces were clarified and titrated by IIF in HRT 18 cells (15) and/or examined by negative staining.

Tissue sections ( $8 \mu \mathrm{m}$ in thickness) were fixed in acetone and then examined by IIF. The sections were incubated with rabbit CV Paris antiserum or control serum at a dilution of 1/100 in Dulbeco's phosphate buffered saline (PBSA) (Oxoid 
Ltd., Basingstoke, Hampshire) and then with fluorescein-conjugated sheep antiserum to rabbit immunoglobulin $G$ at a dilution of $1 / 30$ in PBSA and counterstained with 0.1 per cent Evans blue. Controls were uninfected cells tested as above and infected cells tested with (a) pre-immune rabbit serum and (b) rabbit antiserum to bovine viral diarrhoea virus (BVDV) and (c) rabbit antiserum to herpesvirus of bovine malignant catarrhal fever (MCFV) (23). Further controls included tissues from two conventional calves infected with MCFV tested against CV Paris antiserum and tissues from the CV Paris infected calf tested with (a) pre-immune rabbit serum, (b) rabbit antiserum to BVDV and (c) rabbit antiserum to MCFV. The immune CV Paris serum had a titre of 1/1000 by IIF.

No fever was recorded in the calf from birth until autopsy 3 days after virus inoculation. The animal refused its feed on the 2 nd day after inoculation and thereafter; there was also an obvious change from dark brown tenacious faeces to yellow at this stage. The animal had bright yellow fluid faeces prior to necropsy on the 3 rd day after inoculation.

Gram negative rods and fringed particles were detected in faeces from 2 days onwards after hysterotomy. Both these agents were considered to be non pathogenic contaminants since no clinical abnormalities were detected before the calf was inoculated with CV Paris at 10 days of age. No virus was isolated from faeces or rectal, conjunctival and throat swabs taken before inoculation.

No virus was isolated from throat or conjunctival swabs taken 1,2 and 3 days after virus inoculation. Increasing amounts of infectious coronavirus particles were detected by IIF in faeces and rectal swab washings taken 1, 2 and 3 days after virus inoculation (Table 1). However, coronavirus particles were first detected by EM in faeces taken just before necropsy on the 3 rd day after virus inoculation. Faeces contained $3.8 \times 10^{9}$ particles $/ \mathrm{ml}$; they had a similar morphology to the virus inoculum (Fig. 1) and were agglutinated by CV Paris antiserum. Virus particles were also observed in rectal, abomasum and ileum contents at necropsy; but no particles were seen in the contents of the duodenum and jejunum (Table 2 ).

Table 1. Excretion of infectious virus in the gnotobiotic calf inoculated with CV Paris

\begin{tabular}{llcl}
\hline & \multicolumn{3}{c}{ Days after infection } \\
\cline { 2 - 4 } Sampleb $^{b}$ & 1 & 2 & 3 \\
\hline Conjunctival swab & -ve & - ve & -ve \\
Throat swab & $-v e$ & $-v e$ & $-v e$ \\
Rectal swab & $-v e$ & $1.4 \times 10^{4}$ & $2.6 \times 10^{5}$ \\
Haeces & $5.2 \times 10^{2}$ & $4.4 \times 10^{3}$ & $2.0 \times 10^{7}$ \\
\hline
\end{tabular}

a Infectious virus was determined by IIF and calculated as $\mathrm{PFU} / \mathrm{ml}$

b Swabs were washed in $1 \mathrm{ml}$ RPMI maintenance medium. Preinoculation samples were negative for infectious virus

Pathologically, no macroscopic abnormalities were observed in the GI tract, although there was a loss of epithelium from the tips of the shortened villi of the ileum. Foci of necrosis occurred within the submucosal lymphoid tissue at this level with a migration of neutrophils into the mucosa and lumen. In the colon a 


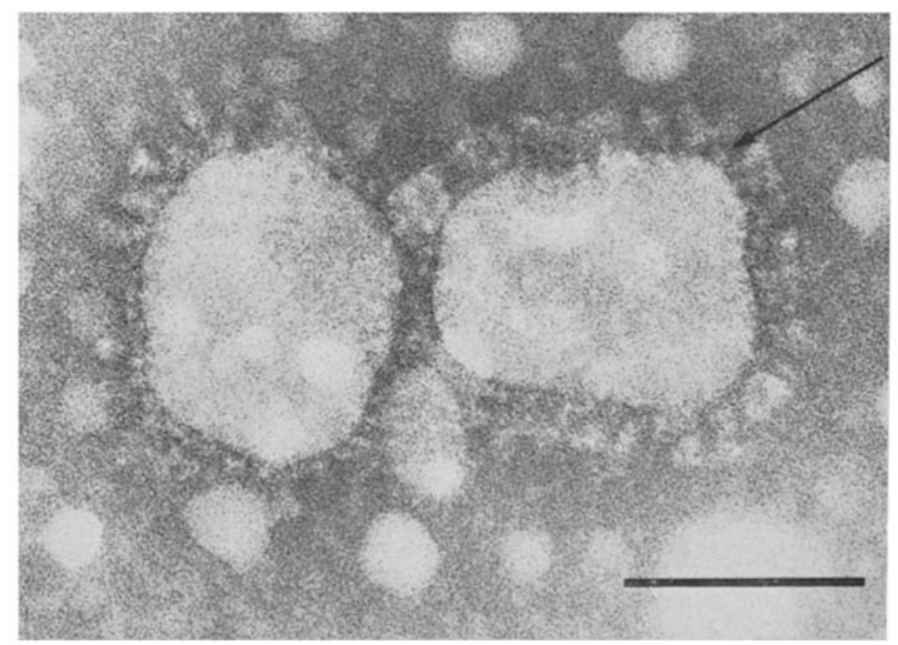

Fig. 1. Two negatively stained virus particles found in the faeces taken 3 days postinoculation. Note the short set of surface projections (arrowed), $5-10 \mathrm{~nm}$ long, and the longer set 17-23 nm long. Approximately half of the particles had both sets of projections. Bar represents $100 \mathrm{~nm}$

similar aggregation of neutrophils in the crypts, associated with a change from columnar to cuboidal epithelium gave rise to micro-abscesses as described by Merus et al. (20). However, these histological changes in the colon were not always positive by IIF.

Table 2. Presence of $C V$ Paris in the gastrointestinal tract of the gnotobiotic calf killed 3 days after inoculation

\begin{tabular}{|c|c|c|c|c|}
\hline \multirow[b]{2}{*}{ Sample } & \multicolumn{2}{|c|}{ Infectivity } & \multirow[b]{2}{*}{$\begin{array}{l}\text { Fluorescent foci in } \\
\text { tissue sections }{ }^{\circ}\end{array}$} & \multirow{2}{*}{$\begin{array}{l}\text { Virus } \\
\text { particles } \\
\text { in lumend }\end{array}$} \\
\hline & $\begin{array}{l}\text { Tissue } \\
\text { suspension }^{\text {a }}\end{array}$ & Lumen ${ }^{b}$ & & \\
\hline Abomasum & $4.5 \times 10^{2}$ & -ve & Very occasional & $3.4 \times 10^{5}$ \\
\hline Duodenum & $1.7 \times 10^{4}$ & -ve & Occasional & N.O.e \\
\hline Jejunum & $2.3 \times 10^{4}$ & -ve & Occasional & N.O. \\
\hline Пleum & $4.7 \times 10^{4}$ & -ve & Occasional & $5.5 \times 10^{6}$ \\
\hline Colon & $7.0 \times 10^{6}$ & $6.6 \times 10^{6}$ & Frequent & N.D. ${ }^{?}$ \\
\hline Rectum & $6.8 \times 10^{6}$ & $8.2 \times 10^{6}$ & Frequent & $6.9 \times 10^{7}$ \\
\hline
\end{tabular}

a $\log _{10} \mathrm{PFU} / \mathrm{g}$ wet tissue; determined by IIF in 10 per cent w/v suspension

b $\log _{10} \mathrm{PFU} / \mathrm{ml}$ lumen contents; determined by IIF in 10 per cent $\mathrm{w} / \mathrm{v}$ suspension

c Antigen-positive cells were restricted to the villous epithelium. Occasional foci $=2-5$ fluorescent cells per 3 or more fields of view, frequent foci $\equiv 3-4$ foci of $5-20$ fluorescent cells per field; viewed at a magnifieation of $200 \times$

a Virus particles $/ \mathrm{ml}$ lumen contents; determined using latex spheres on 10 per cent w/v suspensions by electron microscopy

- N.O. None observed

I N.D. Not done 
The results of the virus isolation are summarized in Table 2; only the GI tract was infected. The colon and rectum yielded about $10^{7} \mathrm{PFU}$ of virus/g wet tissue and approximately $10^{4} \mathrm{PFU}$ of virus/g wet tissue was recovered from duodenum, jejunum and ileum. The abomasum contained a very low titre of virus.

There was good correlation between the detection of virus by EM and IIF. Using IrF, occasional foci of 2 to 3 antigen-positive epithelial cells were seen in the villi of the duodenum, jejunum and ileum: very few infected cells were seen in the abomasum. Most virus replication was seen in the colon and rectum; 3 or 4 foci of 4 to 20 infected cells per field of view were seen at a magnification of $200 \times$. At these sites, infection usually involved the apical half of the villi (Fig. 2). Infected cells contained virus antigen distributed diffusely thoughout the cytoplasm. (Fig. 2). No fluorescent staining was seen in tissue sections tested with preimmune rabbit serum or with MCFV or BVDV rabbit antisera. Furthermore no fluorescence was seen in the duodenum, jejunum, ileum, colon or rectum from two conventional calves infected with MCFV and tested with CV Paris antiserum.

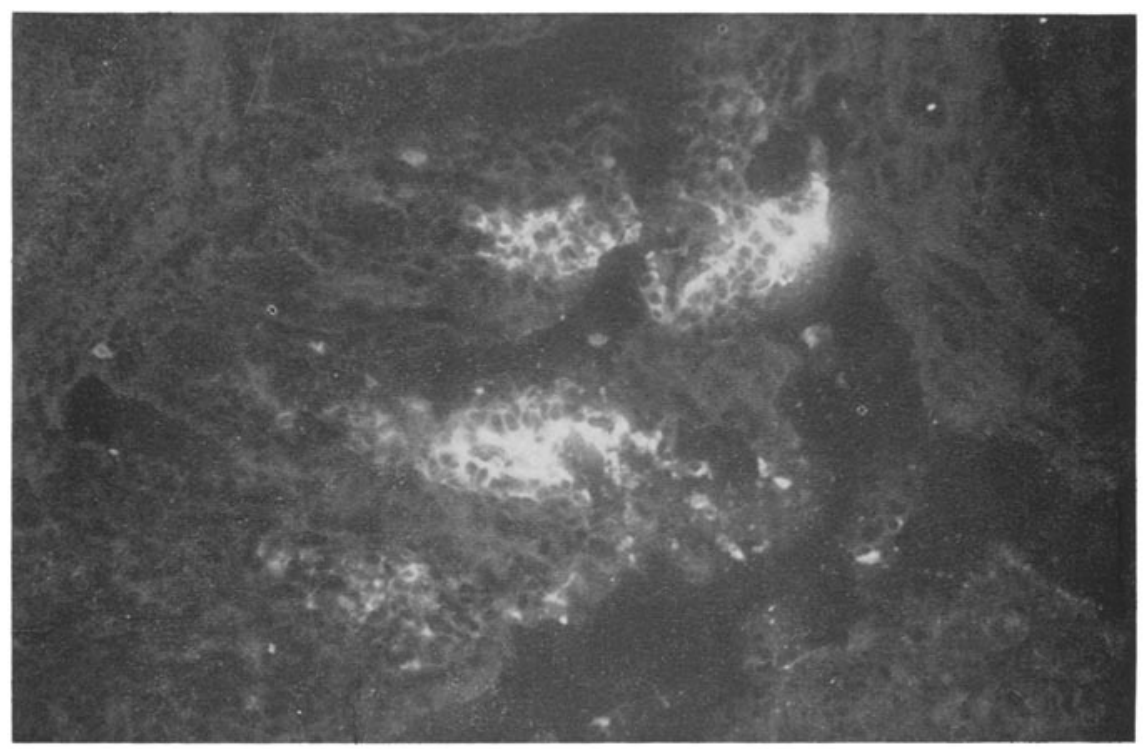

Fig. 2. Fluorescent foci of CV Paris-infected epithelial cells of the colon, where foci are usually seen in the apical half of the villi. Magnification $\times \mathbf{1 8 0}$

Virus particles were found by EM in the cells of the epithelial layer in the colon and rectum. The epithelium of the jejunum and ileum contained no virus particles. Cells containing virus were found in the intact epithelium of the colon and rectum and also free in the lumen of the rectum, but goblet cells and epithelial cells contained virus particles. The virus-infected cells were focal and each focus consisted of one to ten cells.

The changes observed were consistent with coronavirus morphogenesis reported elsewhere $(1,24,30)$. Cells containing virus had lost their microvilli and the rough 
endoplasmic reticulum was distended and contained amorphous material. Virus particles were found in the distended cisternae of the smooth endoplasmic reticulum. (Fig. 3 a), near and within the dilated cisternae of the Golgi apparatus, in intracytoplasmic vesicles and occasionally free in the cytoplasm. The virus-containing vesicles were either scattered randomly throughout the cells, or situated at the base or the apex of the cells. The vesicles found in goblet cells appeared to coalesce with the mucous droplets whereas those in the epithelial cells appeared to be released by cell lysis. The virus particles were similar to those previously reported in HRT 18 cells (14) (Fig. 3b). No "virus factories" or tubules were observed (7).

Our results show that CV Paris induced diarrhoea in a gnotobiotic calf and that 3 days after inoculation the whole of the GI tract was infected, in particular the colon and rectum. However, as we only examined one infected animal, the relative susceptibility of the epithelium at different sites in the GI tract is unclear. Early $\mathrm{BCV}$ replication occurs in the middle small intestine although the virus subsequently spreads to the colon (19).
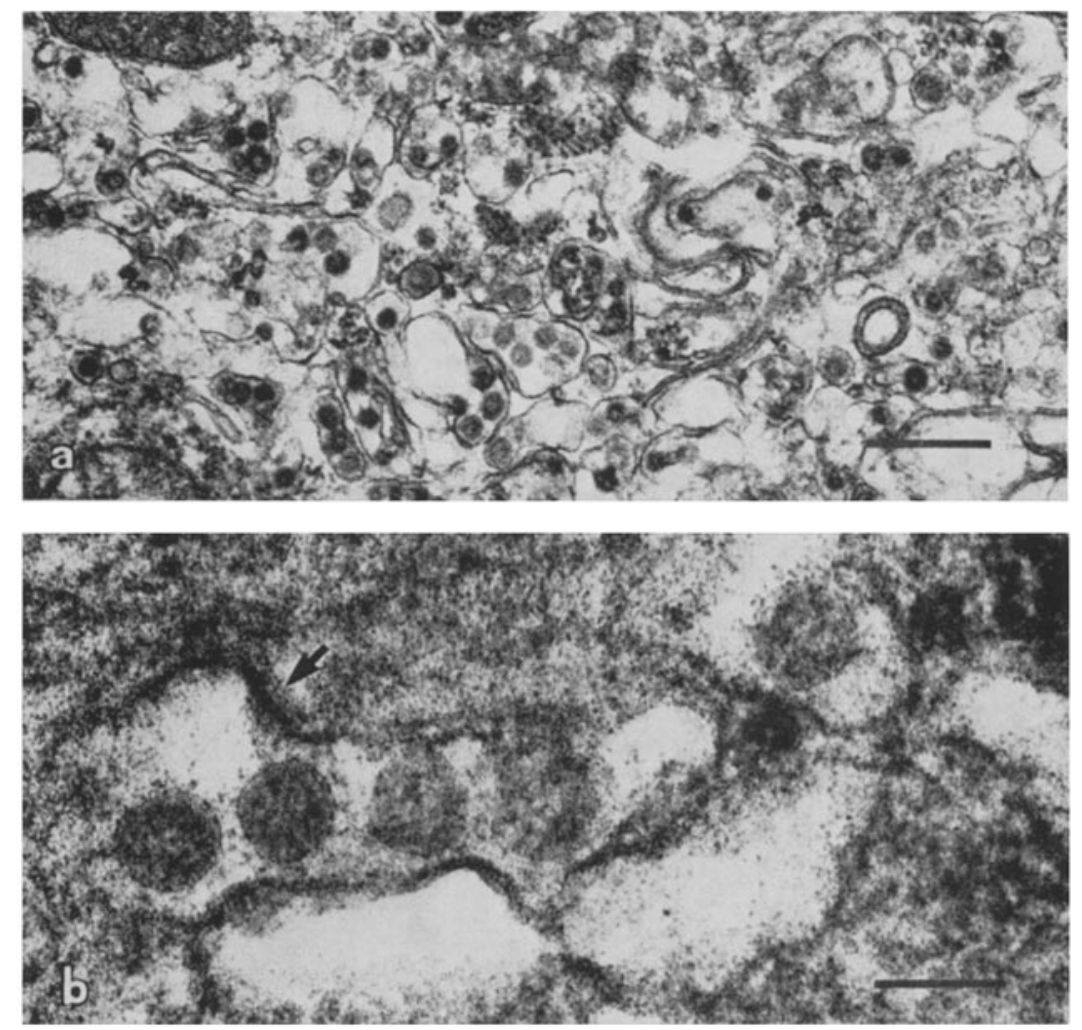

Fig. 3. Micrographs of CV Paris-infected epithelial cells. Tissues were fixed in glutaradehyde, post fixed in osmium tetroxide and stained en bloc with uranyl acetate. Ultrathin sections were stained with lead citrate. $a$ Virus particles within extensive distended smooth endoplasmic retioulum. Bar represents $5 \mu \mathrm{m}$. $b$ Virus particles, surrounded by a trilamellar membrane, seen within the distended eisternum of the smooth endoplasmic reticulum. Budding may be apparent (see arrowed particle). Bar represents $100 \mathrm{~nm}$ 
Our results showed that CV Paris had a predilection for the GI tract since there was no evidence of virus growth in other tissues. There was no detectable infection of the epithelia of throat, trachea, lungs and mesenteric lymph nodes. $\mathrm{BCV}$ has been isolated from lungs and mesenteric lymph nodes of experimentally infected calves (19) and TGEV has been isolated from many organs of infected pigs (D. J. GaRwes, personal communication). However, it is not possible to exclude the possibility that earlier low grade infection had cleared from other tissues, particularly the mesenteric lymph nodes, by the time that the calf was examined. Similarly, it might be argued, that the cuboidal epithelium of the microabscesses in the colon was a regenerative lesion in the pathogenesis of infection and would not therefore be antigen-positive by IIF. The pathology of infection and the distribution of virus at 72 hours after inoculation is similar to that expected for BCV (20).

The definition of $\mathrm{CV}$ Paris presents difficulties. The virus was an isolate from the faeces of a human neonate with necrotising enterocolitis (29). Fringed particles, not typical coronaviruses, were seen by EM in faecal samples from this child (29). Samples of this material were passaged in HRT 18 cells and after several passages infectious CV Paris particles were obtained. Three other isolates were made on different occasions from other children during the same outbreak of necrotising enterocolitis using new batches of medium and serum as control diluents (LAPORTE, unpublished results). CV Paris closely resembles BCV in its growth characteristics in tissue culture, its agglutination of erythrocytes and its polypeptide profile (12; LAPORTE, unpublished results).

The study described in this paper still does not identify the origin and nature of CV Paris but provides us with further useful information concerning this virus. Its replication in a gnotobiotic calf followed the typical pattern observed for enteric coronaviruses, and resembles that described for BCV. We conclude that CV Paris is either BCV or a human enteric coronavirus both having specificity for at least two hosts. The recent observation of a case of possible transmission of $\mathrm{BCV}$ from calves to man (28) is perhaps indicative of a wider host range of BCV than has previously been recognized. Several other studies have identified alternative hosts for coronaviruses. For example, TGEV can infect cats (25) and dogs (21) as well as pigs, and feline and canine coronaviruses can infect newborn pigs (33). In order to resolve further the origin and nature of CV Paris, studies are required to see if $\mathrm{CV}$ Paris can produce enteric disease in man.

\section{Acknowledgments}

We wish to thank the Welleome Trust for financial support.

\section{References}

1. Broker, W. B., MoIntosh, K., Dees, J, H., Cranock, R. M.: Morphogenesis of avian infectious bronchitis virus and related human virus (strain $229 \mathrm{E}$ ). J. Virol. 1, 1019-1027 (1967).

2. Broderson, J. R., Murphy, F. A., Hrerholzar, J. C.: Lethal enteritis in infant mice caused by mouse hepatitis virus. Lab. Anim. Sci. 26, 824 (1976).

3. CaUt, E. O., Crarke, S. K. R.: Coronaviruses propagated from patient with nonbacterial gastroenteritis. Lancet ii, 853-854 (1975). 
4. Caul, E. O., Egqlestone, S. I.: Further studies on human enterie coronaviruses. Arch. Virol. 54, 107-117 (1977).

5. CAUt, E. O., EgGlestone, S. I. : Coronavirus-like particles present in simian faeces. Vet. Rec. 104, 168-169 (1979).

6. CaUt, E. O., Paver, W. K., Clarke, S. K. R.: Coronavirus particles in faeces in patients with gastroenteritis. Lancet i, 1192 (1975).

7. Doughri, A. M., Storz, J., Majer, I., Fernando, H. S.: Morphology and morphogenesis of a coronavirus infecting intestinal epithelial cells of newborn calves. Exp. Mol. Pathol, 25, 355-370 (1976).

8. Frewett, T. H., Bryden, A. S., Davies, H. A.: Diagnostic electron microscopy of faeces. 1. The viral flora of the faeces as seen by electron microscopy. J. Clin. Path. 27, 603-608 (1974).

9. Harada, K., Kumagai, T., Sasahara, J.: Cytopathogenicity of transmissible gastroenteritis virus in pigs. Nat. Inst. Anim. Hlth. Quart 3, 166 167 (1963).

10. Hoshrso, Y., Scotr, F. W.: Coronavirus-like particles in the faeces of normal cats. Arch. Virol, 63, 147-152 (1980).

11. Kraft, L. M.: An apparently new lethal virus disease of infant mice. Science 137, $282-283(1962)$.

12. Laponte, J., BoButesco, P.: Growth of human and canine enteritic coronaviruses in a highly susceptible cell line - HRT-18. In: Poldard, M. (ed.), Perspectives in Virology, Vol. XI, 189-193. New York: Alan R. Liss 1981.

13. Laporte, J., Bobulesco, P., Rossr, F.: Une lignée cellulaire particulièrement sensible à la réplication du coronavirus entéritique bovin: les cellules HRT-18. C. R. Acad. Sc. Paris 230, 623-626 (1980).

14. Macnaughton, M. R., Davies, H. A.: Human enteric coronaviruses. Arch. Virol. 70, $301-313(1981)$.

15. Macnadafton, M. R., Thomas, B. J., Davies, H. A., Patterson, S.: Infectivity of human coronavirus strain $229 \mathrm{E}$. J. Clin. Microbiol, 12, 493-497 (1980).

16. MoCluRKn, A. W.: Studies on transmissible gastroenteritis of swine. 1 Isolation and identification of a cytopathogenic virus of transmissible gastroenteritis in primary swine kidney cells cultures. Canad. J. Comp. Med. 30, 190-198 (1960).

17. Mathan, M., Mathan, V. I., Swaminathan, S. P., Yesudoss, S., Baker, S. J.: Pleomorphic virus-like particles in human faeces. Lancet $\mathbf{i}, 1068-1069$ (1975).

18. MoNulty, M. S., Curran, W. L., McFerran, J. B.: Virus-like particles in calves' faeces. Lancet ii, $78-79(1975)$.

19. Merus, C. A., Rhodes, M. B., UnderdahI, N. R., Twiehaus, M. J.: Neonatal calf diarrhea; propagation, attenuation, and characteristics of a coronavirus-like agent. Amer. J. Vet. Res. 34, 145-150 (1973).

20. Mebus, L. A., Stair, E. L., Rhodes, M. B., Twiehaus, M. J.: Pathology of neonatal calf diarrhoea induced by a coronavirus like agent. Vet. Path. 10, $45-64$ (1973).

21. Norman, J. O., MoClurkin, A. W., Stark, S. L.: Transmissible gastroenteritis (TGE) of swine: canine serum antibodies against an associated virus. Canad. J. Comp. Med. 34, 115-117 (1970).

22. PANTGRAPHY, B., NAQI, S. A., HALI, C. F.: Isolation and characterization of viruses associated with transmissible enteritis (bluecomb) of turkeys. Av. Dis. 17, $430-438(1973)$.

23. Patke, J. R., Edington, N.: The detection and behaviour of the herpesvirus of malignant catarrhal fever in bovine lymphocytes. Arch. Virol. 68, 321-326 (1981).

24. Pensaert, M., Haelterman, E. O., Hinsman, E. J.: Transmissible gastroenteritis of swine: virus-intestinal cell interactions. II. Electron microscopy of the epithelium in isolated jejunal loops. Arch. ges. Virusforsch. 31, 335-351 (1970).

25. ReynotDs, D. J., GARWES, D. J.: Virus isolation and serum antibody responses after infection of cats with transmissible gastroenteritis virus. Arch. Virol. 60, $161-166(1979)$.

26. Schnagl, R. D., Holmes, I. H.: Coronavirus-like particles in stools from dogs from some country areas of Australia. Vet. Rec. 102, 528-529 (1978). 
27. Schnagl, R. D., Holmes, I. H., Mackay-Scoltay, E. M. : Coronavirus-like particles in Aboriginals and Non-Aboriginals in Western Australia. Med. J. Aust. 1, 307-309 (1978).

28. Sronz, J., Rorr, R.: Reactivity of antibodies in human serum with antigens of an enteropathogenic bovine coronavirus. Med. Microbiol. Immunol. 169, 169-178 (1981).

29. Sureat, C., Amiel-Tison, C., Moscovici, O., Lebon, P., Laponte, J., Chany, C.: Une épidémie d'enterocolitis ulcéronécrosantes en maternité, Arguments en faveur de son origine virale. Bull. Acad. Nat. Méd. 164, 286-293 (1980).

30. Takeuch, A., Binn, L. N., Jervis, H. R., Keenan, K. P., Hudebrandt, P. K., VALAS, R. B., BLAND, F. F, : Electron microscopy study of experimental enteric infection in neonatal dogs with a canine coronavirus. Lab. Invest. 34, 539-549 (1976).

31. Tompkixs, W. A. F., Watrach, A. M., Schmale, J. D., Scholtz, R. M., Harris, J. A.: Cultural and antigenic properties of newly established cell strains derived from adenocarcinomas of the human colon and rectum. J. Natl. Cancer Inst. 52, $1101-1110(1974)$.

32. Trexuer, P. C.: Microbiological isolation of large animals. Vet. Rec. 88, 15-18 (1971).

33. Woods, R. D., Cheville, N. F., Gallagher, J. E.: Lesions in the small intestine of newborn pigs inoculated with porcine, feline, and canine coronaviruses. Amer. J. Vet. Res. 42, 1163-1169 (1981)

Authors' address: Dr. M. R. Macnavghton, Division of Communicable Diseases, Clinical Research Centre, Watford Road, Harrow, Middlesex HA 1 3UJ, United Kingdom.

Received March 18, 1982 